\title{
PENENTUAN KURVA BAKU UJI FARMAKOKINETIK TETRA HIDROXY ETHYL DISULPHAT (THES) PADA KELINCI (Orytolagus cuniculus), MARMUT (Cavia porcellus), DAN TIKUS (Rattus novergicus)
}

\author{
Sri Yolandari, Elly Wahyudin dan Yusnita Rifai \\ Fakultas Farmasi, Universitas Hasanuddin, Makassar
}

Kata Kunci :

Tetra Hidroxy Ethyl Disulphat (THES), UFLC, Kurva baku

Masuk 01-08-2018

Revisi 25-08-2018

Diterima 30-08-2018

Korespondensi

\section{Elly Wahyudin}

ellywahyudins@gmail.com

Copyright

(C) 2018 Majalah Farmasi Farmakologi Fakultas

Farmasi · Makassar

Diterbitkan tanggal

31-08-2018

Dapat Diakses Daring

Pada:

http://journal.unhas.ac.id

/index.php/mff

\begin{abstract}
ABSTRAK
Tetra hydroxy ethyl disulfate (THES) merupakan salah satu senyawa hasil sintesis yang baru ditemukan dan memiliki efek sebagai antibiotik yang dapat mengatasi masalah resistensi pada bakteri dengan mekanisme kerja merusak dinding sel bakteri dengan cara mengikat peptidoglikan yang ada pada dinding sel bakteri dengan ligan sulfat yang ada pada THES. Senyawa THES sangat dibutuhkan saat ini dan potensial untuk diproduksi oleh industri. Penelitian ini bertujuan menentukan kurva baku pada THES pada kelinci (Oryctolagus cuniculus), marmut (Cavia porcellus) dan tikus (Rattus novergicus). Berdasarkan hasil penelitian yang dilakukan, diperoleh kondisi optimum pemisahan menggunakan metode eluasi gradien dengan komposisi fase gerak buffer phosphat : asetonitril dengan perbandingan 7 : 3 dan laju alir $1 \mathrm{ml} /$ menit. Untuk panjang gelombang analisis terpilih yaitu panjang gelombang $254 \mathrm{~nm}$, dan waktu retensi 2,3 menit. Hasil penelitian menunjukkan Nilai regresi dari kurva baku larutan THES pada hewan uji kelinci sebesar 0,943 dengan persamaan $y=22857 x+1265$, pada hewan uji marmut sebesar 0,835 dengan persamaan y =2963.x - 10817, pada hewan uji tikus sebesar 0,906 dengan persamaan $\mathrm{y}=56586 \mathrm{x}-11474$. Adanya perbedaan yang diperoleh dengan literatur yang ada kemungkinan disebabkan adanya zat pengotor dari larutan uji, namun namun hasil ini tidak terlalu jauh dari literatur yang ada, sehingga masih dapat digunakan sebagai acuan
\end{abstract}

\section{PENDAHULUAN}

Berbagai studi menemukan bahwa sekitar 40$62 \%$ antibiotik digunakan secara tidak tepat antara lain untuk penyakit-penyakit yang sebenarnya tidak memerlukan antibiotik. Intensitas penggunaan antibiotik yang relatif tinggi menimbulkan berbagai permasalahan dan merupakan ancaman global bagi kesehatan terutama resistensi bakteri terhadap aktivitas kerja antibiotik. Resistensi dapat dicegah dengan memberikan terapi antibiotik spesifik yang diberikan berdasarkan kultur dan resistensi kuman, mengkonsumsi antibiotik sesuai dengan dosis dan jangka waktu yang benar (1).

Seiring dengan perkembangan zaman, kebutuhan manusia akan obat juga semakin berkembang. Hal ini sejalan dengan prevalensi penyakit yang semakin sering bermunculan. Usaha penemuan obat baru baik dari bahan alam maupun sintetik terus dilakukan untuk mencapai efektifitas terapi yang optimal. Obat-obat baru diharapkan dapat menjadi obat pilihan dengan efek maksimal, efek samping minimal serta toksisitas yang minimal. Salah satu upaya untuk mengetahui hal tersebut, maka dilakukan berbagai penelitian spesifik tentang obat agar diketahui karakteristik suatu obat baik bagaimana efeknya maupun bagaimana nasib obat didalam tubuh (1).

Seiring perkembangan teknologi dibidang kefarmasian banyak obat-obatan baru telah ditemukan dalam berbagai bentuk baik dari senyawa hasil ekstraksi maupun sintesis senyawa baru. Salah satunya adalah Haryono wardoyo yang melakukan penelitian terkait modifikasi EDTA dan ditemukan
THES (Tetra hydroxy ethyl disulfate) yang digunakan sebagai novel non resistant antibacteri (2).

Tetra hydroxy ethyl disulfate (THES) merupakan salah satu senyawa hasil sintesis yang baru ditemukan dan memiliki efek sebagai antibiotik yang dapat mengatasi masalah resistensi pada bakteri dengan mekanisme kerja merusak dinding sel bakteri dengan cara mengikat peptidoglikan yang ada pada dinding sel bakteri dengan ligan sulfat yang ada pada THES. Senyawa THES sangat dibutuhkan saat ini dan potensial untuk diproduksi oleh industri (2).

Namun kurva baku profil farmakokinetik dari senyawa ini belum didapatkan sehingga perlu dilakukan pengembangan kurva baku uji farmakokinetik senyawa Tetra hydroxy ethyl disulfate (THES). Kurva baku merupakan standar dari sampel yang dapat digunakan sebagai acuan untuk sampel tersebut pada percobaan. Pembuatan kurva standar bertujuan mengetahui hubungan antara konsentrasi larutan dengan nilai luas area sehingga konsentrasi sampel dapat diketahui (3).

Berdasarkan hal tersebut diatas, maka akan dilakukan penelitian profil farmakokinetik senyawa sintetik Tetra Hidroxy Ethyl Di Sulphat (THES). Penelitian ini bertujuan untuk menentukan kurva baku uji farmakokinetik senyawa sintetik Tetra Hidroxy Ethyl Di Sulphat (THES) pada) kelinci (Oryctolagus cuniculus), marmut (Cavia porcellus) dan tikus (Rattus novergicus). 


\section{METODE PENELITIAN}

\section{Alat dan Bahan Penelitian}

Alat-alat yang digunakan dalam penelitian ini adalah alat-alat gelas, kanula, magnetic stirer, membran filter, mikropipet 100-1000 $\mu \mathrm{l}$, needle, penyaring UFLC, sonikator, sentrifuse, spoit, timbangan analitik, termometer, tip mikropipet, tabung sentrifuge, stopwatch, ultra fast liquid chromatography (UFLC), vial autosampler, vortex.

Bahan-bahan yang digunakan dalam penelitian ini adalah aquadest aquadest pro injeksi, asetonitril, buffer phosphate, dan senyawa Tetra Hidroxy Ethil Di Sulphate (THES)

\section{Pemilihan Hewan Uji}

Penelitian ini menggunakan rancangan acak lengkap dengan tikus, kelinci, marmut sebagai hewan percobaan dibagi dalam 3 kelompok, masing-masing terdiri dari 3 ekor. Hewan uji pertama yang digunakan adalah Tikus Putih (Rattus norvegicus) jantan yang sehat dan aktivitas normal, dengan bobot badan antara 100-200 gram (4). Hewan uji kedua yang digunakan adalah kelinci jantan berumur 4-6 bulan dengan bobot badan 1.5-2.5 kg yang telah dikarantina untuk menyesuaikan diri dengan lingkungannya selama kurun waktu satu minggu (4). Hewan uji ketiga yang digunakan adalah marmut (Cavia porcellus) yang sehat dan aktivitas normal, dengan bobot badan rata rata 400-600 gram (4).

\section{Pembuatan Larutan Baku}

THES ditimbang sebanyak $10 \mathrm{mg}$ dan dimasukkan kedalam labu tentukur $10 \mathrm{ml}$, larutkan dengan pelarut aquadest pro injeksi dan dicukupkan sampai volume batas sehingga diperoleh konsentrasi larutan 1000 bpj (larutan stok). Larutan stok kemudian masing-masing dipipet $100 \mu \mathrm{L}, 200$ $\mu \mathrm{L}, 300 \mu \mathrm{L}, 400 \mu \mathrm{L}$, dan $500 \mu \mathrm{L}$ dalam masing-masing labu tentuukur $10 \mathrm{ml}$ sehingga diperoleh konsentrasi larutan 10 ppm, 20 ppm, 30 ppm, 40 ppm dan 50 ppm.

\section{Penyiapan Plasma Darah}

Cuplikan darah masing masing hewan uji ditambahkan larutan Natrium EDTA sebanyak 0,1 ml, kemudian masing masing sampel ditampung dalam tabung effendorf, lalu disentrifuge pada kecepatan $5000 \mathrm{rpm}$ selama 15 menit, kemudian endapannya dipisahkan dengan cara enap tuang dan sampel plasma yang diperoleh dimasukkan ke dalam freezer $20^{\circ} \mathrm{C}$ sebelum diekstraksi dan dianalisa.

\section{Pembuatan Kurva Baku}

Larutan baku yang telah dibuat, masing masing diambil sebanyak $100 \mu \mathrm{l}$ ditambahkan kedalam $50 \mu$ l plasma dan 400 $\mu \mathrm{l}$ asetonitril grade HPLC sebagai pengendap protein. Campuran divortex selama 5 menit dan disentrifuge dengan kecepatan 12000 RPM selama 20 menit. Diambil supernatan dan disaring menggunakan penyaring khusus UFLC dan disuntikkan sebanyak $20 \mu \mathrm{l}$ kedalam UFLC, dengan fase diam kolom ODS C18 dengan suhu kolom $30^{\circ} \mathrm{c}$. Luas area dari masing masing kromatogram sampel yang diperoleh digunakan untuk menentukan kurva baku senyawa sintetik THES dalam sampel plasma.

\section{Interpretasi Data}

Nilai luas area senyawa sintetik THES dalam plasma diplot terhadap variasi konsentrasi pada perangkat lunak Microsoft Excel 2010 dalam bentuk gambar kurva baku. Dari gambar tersebut dapat ditentukan nilai $\mathrm{R}$ kurva baku uji farmakokinetik THES pada kelinci, marmut, dan tikus.

\section{HASIL DAN PEMBAHASAN}

Kromatografi Cair Kinerja Tinggi (KCKT) merupakan suatu metoda pemisahan canggih dalam analisis farrnasi yang dapat digunakan sebagai uji identitas, uji kemumian dan penetapan kadar. Titik beratnya adalah untuk analisis senyawa senyawa yang tidak mudah menguap dan tidak stabil pada suhu tinggi, yang tidak bisa dianalisis dengan Kromatografi Gas. Banyak senyawa yang dapat dianalisis, dengan KCKT mulai dari senyawa ion anorganik sampai senyawa organik makromolekul. Untuk analisis dan pemisahan obat /bahan obat campuran rasemis optis aktif dikembangkan suatu fase pemisahan kiral (chirale Trennphasen) yang mampu menentukan rasemis dan isomer aktif. Pada penelitian ini menggunakan KCKT (UFLC) fase terbalik, kckt jenis ini, ukuran kolomnya sama, tetapi silika dimodifikasi menjadi non-polar melalui pelekatan hidrokarbon dengna rantai panjang pada permukaannya secara sederhana baik berupa atom karbon 8 atau 18. Dalam kasus ini, akan terdapat interaksi yang kuat antara pelarut polar dan molekul polar dalam campuran yang melalui kolom. Interaksi yang terjadi tidak sekuat interaksi antara rantai-rantai hidrokarbon yang berlekatan pada silika (fasa diam) dan molekul-molekul polar dalam larutan. Oleh karena itu molekul-molekul polar akan lebih cepat bergerak melalui kolom. Sedangkan molekul-molekul non polar akan bergerak lambat karena interaksi dengan gugus hidrokarbon (4). Teknik pola kromatogram dengan menggunakan metode KCKT (UFLC) ini memerlukan kondisi yang optimum untuk dapat menghasilkan pola kromatogram terbaik yang dapat digunakan sebagai database yang dapat diperoleh melalui optimasi komposisi fase gerak dan panjang gelombang analisis. Berdasarkan hasil penelitian yang dilakukan, diperoleh kondisi optimum pemisahan menggunakan metode eluasi gradien dengan komposisi fase gerak buffer phosphat: asetonitril dengan perbandingan $7: 3$ dan laju alir $1 \mathrm{ml} / \mathrm{menit}$. Untuk panjang gelombang analisis terpilih yaitu panjang gelombang $254 \mathrm{~nm}$, dan waktu retensi 2,3 menit (5).

\begin{tabular}{ccc}
$\begin{array}{l}\text { Tabel 1. Data hubungan antara seri kadar THES dan luas area untuk } \\
\text { kurva baku kelinci }\end{array}$ \\
\hline No & $\begin{array}{c}\text { Seri kadar } \\
(\mu \mathrm{g} / \mathrm{mL})\end{array}$ & Luas area \\
\hline 1 & 10 & 31578 \\
2 & 20 & 42141 \\
3 & 30 & 57639 \\
4 & 40 & 101777 \\
5 & 50 & 116045 \\
\hline
\end{tabular}

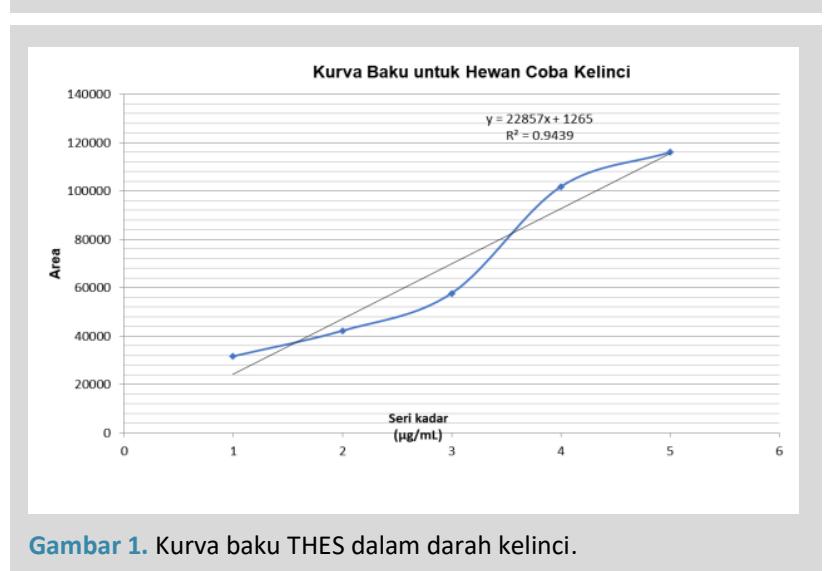

Kurva baku digunakan untuk mendapatkan nilai yang proposional terhadap konsentrasi analit dalam sampel, adanya sedikit penyimpangan pada kurva diakibatkan oleh berbagai faktor seperti katan ion yang tinggi, serta reaksi ikutan yang terjadi (6). Sedangkan nilai regresi yang baik 
adalah mendekati 1 karena kesalahan inilah yang menyebabkan garis kurva kalibrasi tidak linear (garis lurus). Namun hasil ini tidak terlalu jauh dari literatur yang ada, sehingga masih dapat digunakan sebagai acuan. Persamaan kurva baku pada kelinci yang diperoleh berdasarkan table 1 dan gambar 1 adalah $\mathrm{y}=22857 \mathrm{x}+1265$; $\mathrm{x}$ adalah kadar THES dalam darah dan y adalah luas area dibawah puncak kromatogram THES hasil dari pengukuran dengan UFLC, nilai $r$ yang diperoleh adalah 0.943 . Nilai r pada hasil regresi linier menunjukkan linieritas yang baik karena mendekati satu (7). Persamaan kurva baku pada marmut yang diperoleh berdasarkan tabel 2 dan gambar 2 adalah $y=2963 . x-10817$ nilai $r$ yang diperoleh adalah 0.835 . Nilai $r$ pada hasil regresi linier menunjukkan linieritas yang baik karena mendekati satu (7). Persamaan kurva baku pada tikus yang diperoleh berdasarkan table 3 dan gambar 3 adalah $\mathrm{y}=56586 \mathrm{x}-11474$ Nilai r yang diperoleh adalah 0,906 , nilai r pada hasil regresi linier menunjukkan linieritas yang baik karena mendekati satu (7).

Tabel 2. Data hubungan antara seri kadar THES dan luas area untuk kurva baku marmut

\begin{tabular}{ccc}
\hline No & $\begin{array}{c}\text { Seri kadar } \\
(\boldsymbol{\mu g} / \mathrm{mL})\end{array}$ & Luas area \\
\hline 1 & 10 & 37878 \\
2 & 20 & 27582 \\
3 & 30 & 82582 \\
4 & 40 & 85122 \\
5 & 50 & 157286 \\
\hline
\end{tabular}

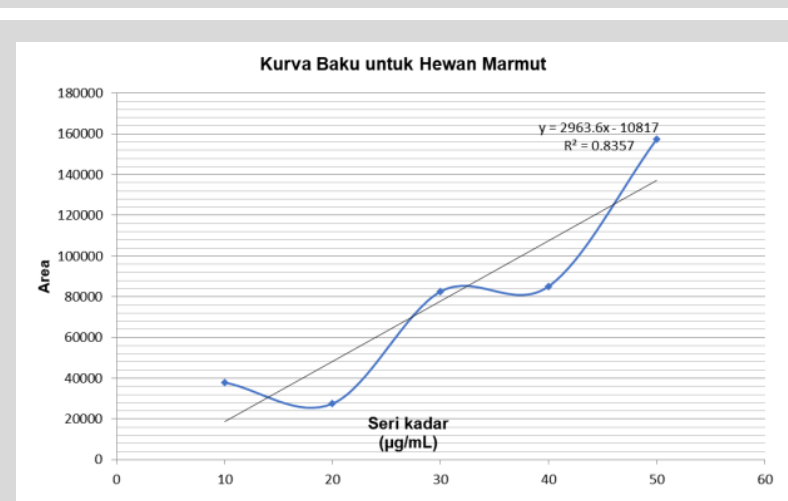

Gambar 2. Kurva baku THES dalam darah marmut

Tabel 3. Data hubungan antara seri kadar THES dan luas area untuk kurva baku marmut

\begin{tabular}{ccc}
\hline No & $\begin{array}{c}\text { Seri kadar } \\
(\mu \mathrm{g} / \mathrm{mL})\end{array}$ & Luas area \\
\hline 1 & $10 \mathrm{ppm}$ & 66116 \\
2 & $20 \mathrm{ppm}$ & 76243 \\
3 & $30 \mathrm{ppm}$ & 134838 \\
4 & $40 \mathrm{ppm}$ & 254114 \\
5 & $50 \mathrm{ppm}$ & 260110 \\
\hline
\end{tabular}

Kurva standar yang diperoleh dengan koefisien korelasi (r) yang berbeda beda didasarkan pada hasil percobaan yang dilakukan dengan panjang gelombang THES sebesar254 nm pada konsentrasi $10 \mathrm{ppm}, 20 \mathrm{ppm}, 30 \mathrm{ppm}, 40 \mathrm{ppm}$, dan 50 ppm. Semakin banyak jumlah zat terlarut dalam larutan maka akan mengakibatkan konsentrasi dan luas areanya semakin besar, koefisien korelasi yang diperoleh untuk hewan uji tikus lebih rendah, hal ini dapat disebabkan berbagai faktor antara lain oleh masih adanya zat pengotor dari larutan tersebut. Pengotor seperti pencucian alat yang tidak bersih dimungkinkan membawa dampak terhadap hasil yang diperoleh dari penelitian ini. Selain itu pula plasma darah yang mengandung senyawa yang kompleks selain protein memungkinkan munculnya berbagai senyawa pada saat diidentifikasi menggunakan UFLC.

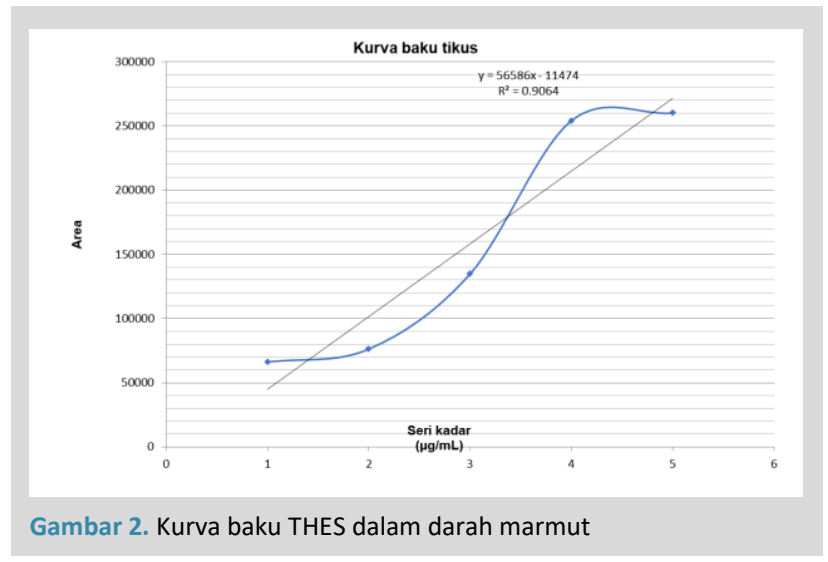

\section{KESIMPULAN}

Nilai regresi dari kurva baku larutan THES pada hewan uji kelinci sebesar 0,943 dengan persamaan $\mathrm{y}=22857 \mathrm{x}+1265$, pada hewan uji marmut sebesar 0,835 dengan persamaan y $=2963 . x-10817$, pada hewan uji tikus sebesar 0,906 dengan persamaan $\mathrm{y}=56586 \mathrm{x}-11474$. Adanya perbedaan yang diperoleh dengan literatur yang ada kemungkinan disebabkan adanya zat pengotor dari larutan uji, namun Namun hasil ini tidak terlalu jauh dari literatur yang ada, sehingga masih dapat digunakan sebagai acuan.

\section{UCAPAN TERIMA KASIH}

Pada kesempatan ini, dengan penuh kerendahan hati kami mengucapkan terima kasih dan penghargaan sebesarbesarnya kepada pembimbing Ibu Prof. Elly Wahyudin, DEA, Apt. dan Ibu Yusnita Rifai, S.Si., M. Pharm., PhD., Apt. Untuk Kedua Orang Tua Tercinta, Ramli, SH dan Nelly normal mamesah. Terima kasih kepada semua pihak yang penulis tidak bias sebutkan satu persatu atas do'a dan motivasi yang senantiasa kalian curahkan dalam setiap keadaan.

\section{DAFTAR PUSTAKA}

1. Ciesla WP, Guerrant RL. 2003. Current Diagnosis and Treatment in Infectious Disease. New York: Lange Medical Books.

2. Leahy, D.E. 2004. Drug discovery information integration: virtual human for pharmacokinetics. Reviews. DDT: BIOSILICO 2.

3. Haryono, wardoyo, 2015. Tetra Hidroxy Ethyl di-Sulfate. Nitricide,Tanggerang.

4. Shargel, L., Yu, A., and Wu, S., 2005, Biofarmasetika dan Farmakokinetika Terapan, Edisi kedua, Airlangga University Press, Surabaya

5. Institute of Laboratory Animal Research (ILR) Commission on Life Sciences, National Research Council. 1996. Guide for the care and use of laboratory animals. Washington (DC): National Academies Press.

6. Gandjar, Ibnu Gholib, dan Abdul Rohman. 2008. Kimia Farmasi Analisis Pustaka Pelajar. Yogyakarta.

7. Watson, D.G. 2000. Pharmaceutical Analysis A text Book For Pharmacy Students and Pharmaceutical Chemists. Churchill livingstone. 